Ilmu Dakwah: Academic Journal for Homiletic Studies Volume 11 Nomor 1 (2017) 21-32 DOI: 10.15575 /idajhs.v11i1.1526

http://journal.uinsgd.ac.id/index.php/idajhs ISSN 1693-0843 (Print) ISSN 2548-8708 (Online)

\title{
Kesenian Tari Topeng sebagai Media Dakwah
}

\author{
Yayah Nurhidayah \\ Institut Agama Islam Negeri Syekh Nurjati, Cirebon \\ "yayahnurh@yahoo.com.au
}

\begin{abstract}
$A B S T R A C T$
Mask dance is one of the artistic potential of traditional media can be used as an alternate to the development of Islam. Elements of traditional and communicative nature of the performing arts, enabling to serve as an effective medium of information, without losing the element of entertainment. Unfortunately, the art of dance performances mask yet empowered as a package for maximum performance as well as guidance. the role of the mask dance used functioned as a medium for the spread of Islam, gradually shrinking. Globalization has led to the emergence of modern cultures and marginalized traditional art, art that potential existence is increasingly squeezed by the presence of popular art, and gradually abandoned his fans and Mask dance more exclusive. Therefore, needs to be revitalized, especially the function and role of the missionary expansion in the future.

Keywords : Mask Danc; Revitalization; Da wah Media
\end{abstract}

\begin{abstract}
ABSTRAK
Tari topeng merupakan salah satu potensi kesenian tradisional yang dapat dijadikan sebagai media aternatif untuk pengembangan dakwah Islam. Unsur tradisional dan sifat komunikatif dari seni pertunjukkan tersebut, memudahkan untuk dijadikan sebagai media penerangan yang efektif, tanpa harus kehilangan unsur hiburannya. Sayangnya, seni pertunjukkan tari topeng belum diberdayakan secara maksimal sebagai paket tontonan sekaligus tuntunan. Peran tari topeng yang dulu difungsikan sebagai media syiar Islam, lambat laun menyusut. Arus globalisasi telah mendorong munculnya kebudayaan-kebudayaan modern dan memarginalisasi kesenian tradisonal, sehingga seni yang potensial ini keberadaannya makin terjepit oleh keberadaan seni populer, dan berangsur-angsur ditinggalkan penggemarnya sehingga tari topengpun makin ekslusif. Oleh karena itu, perlu direvitalisasi terutama makna, fungsi dan perannya untuk pengembangan dakwah di masa depan.
\end{abstract}

Kata Kunci : Tari Topeng; Revitalisasi; Media Dakwah.

\section{PENDAHULUAN}

Dewasa ini pemerintah sedang giat-giatnya menggalakkan kebudayaan daerah, sebab kebudayaan daerah merupakan salah satu potensi yang dapat dijadikan andalan untuk meningkatkan sumber pendapatan daerah 
melalui pariwisata. Berbagai upaya telah dilakukan seperti Program Indonesia Visit Year tahun 1990, Asean Visit Year tahun 1991, Sapta Pesona tahun 1998 dan lainnya. Tetapi, hasil yang dicapai belum maksimal, karena potensi budaya yang ada, salah satunya adalah seni pertunjukkan tari topeng belum diberdayakan secara maksimal sebagai paket tontonan sekaligus tuntunan. Kesenian tradisional tari topeng merupakan salah satu media komunikasi tradisonal, yang dapat diandalkan sebagai media alternatif untuk menyebarkan nilai-nilai ajaran Islam. Karena dalam seni pertunjukan yang satu ini, selain sebagai asset budaya terdapat nilai-nilai religious di dalamnya.

Media komunikasi tradisional, merupakan media yang digunakan oleh masyarakat tertentu yang berbeda dari masyarakat lainnya disebabkan ciri-ciri khas sistem masyarakat tersebut beserta tata nilai kebudayaannya. Media komunikasi tradisional terutama seni pertunjukkan sampai saat ini masih dianggap penting, sebagai alat untuk menyampaikan pesan-pesan pembangunan, terutama pembangunan mental spiritual. Hal ini sejalan dengan pendapat Harmoko (1986:86) sebagai berikut :

Media tradisional adalah berbagai macam seni pertunjukkan yang secara tradisional dipentaskan di depan khalayak terutama sebagai sarana hiburan yang memiliki sifat komunikatif, sehingga bentuk kesenian itu dapat dimanfaatkan sebagai media pembawa pesanpesan penerangan. Unsur tradisional dan sifat komunikatif dari seni pertunjukkan tersebut, memudahkan untuk dijadikan sebagai media penerangan yang efektif, tanpa harus kehilangan unsur hiburannya. Efektifitas tersebut sebagian tersebar disebabkan oleh karena seni pertunjukan memang bersifat merakyat, dan dengan demikian mudah untuk dapat langsung menggugah hati khalayak. Itulah sebabnya bentuk kesenian ini sering disebut sebagai pertunjukkan rakyat.

(Dahuri, Irianto, \& dkk, 2004:11) menjelaskan bahwa pertunjukkan sebuah seni tidak hanya sebagai ungkapan seni semata, tetapi pertunjukkan sebuah seni harus difungsikan sebagai sarana penyebaran agama, dalam konteks ini adalah Islam. Tari topeng Cirebon adalah suatu seni pertunjukkan tradisional Cirebon yang difungsikan sebagai sarana penyebaran Islam. Kini, topeng hanya difungsikan sebagai sarana upacara adat dan hiburan.Selain itu, munculnya gelombang besar globalisasi, telah mendorong munculnya kebudayaankebudayaan modern (barat) dan mengakibatkan kebudayaan tradisional (lokal) mengalami marginalisasi, sehingga seni yang potensial ini 
keberadaannya makin terjepit oleh keberadaan seni populer, karenanya berangsur-angsur ditinggalkan penggemarnya. Tari topengpun makin ekslusif. Oleh karena itu, perlu direvitalisasi dan bahkan diberdayakan untuk pengembangan dakwah di masa depan.

Penelitian yang relevan dengan konteks penelitian ini perlu dikemukakan untuk memetakan posisi penelitian yang akan dilakukan dengan penelitian sebelumnya. Antara lain: penelitian, Arsyanah Sugiarto (2013) berjudul: Tari Topeng Kelana Udeng Di Sanggar Mulya Bhakti Desa Tambi Kecamatan Sleyeg Kabupaten Indramayu. penelitian Indri Arum Fachriya (2011) berjudul: Tari Topeng Endel dalam Perkembangan dan Pelestarian Kesenian Khas Tegal. penelitian, Dhaevatun Fitriyah, Yohanes Hanan Pamungkas (2015) berjudul: Perkembangan Tari Topeng Gethak di Kabupaten Pamekasan pada Tahun 1980-2005. penelitian, Titan Rokhmutiana Hardi (2014) berjudul: Dakwah Sunan Gunung Jati dalam Proses Islamisasi di Kesultanan Cirebon Tahun 1479-1568.

Sejauh pengamatan penulis, penelitian terdahulu masih berkisar pada meneliti sejarah asal usul, perkembangana dan faktor penghambat dan pendorong Tari Topeng. Lokasi penelitian terbatas pada penelitian di sanggar-sanggar kesenian yang ada saat ini, masih sedikit penelitian diarahkan kepada penelusuran sejarah pemanfaatan tari topeng sebagai media alternatif untuk kepentingan penyebaran ajaran Islam (dakwah) sebagaimana dilakukan oleh para penyebar Islam pertama di Cirebon.

Berdasarkan latar belakang masalah di atas, pertanyaan penelitian ini adalah bagaimana pemanfaatan kesenian tari topeng sebagai media untuk penyebaran ajaran Islam di Cirebon? makna-makna apakah yang terkandung dalam kesenian tari topeng Cirebon? bagaimana upaya merevitalisasi tari topeng sebagai media untuk penyebaran ajaran Islam di Cirebon? Bagaimana hambatan merevitalisasi tari topeng sebagai media untuk penyebaran ajaran Islam di Cirebon?

Jenis penelitian ini adalah penelitian kualitatif dengan model pendekatan sejarah. Penelitian ini menggunakan desain penelitian studi kasus. Sumber data dalam penelitian ini terdiri dari sumber data primer dan sekunder. Sumber data primer akan penulis peroleh dari hasil wawancara dengan tokoh-tokoh yang ada di keraton Cirebon, seniman, dan budayawan. Data sekunder diperoleh dengan telaah dokumen dan berbagai sumber rujukan. Tehnik pengumpulan data dilakukan melalui: wawancara mendalam, studi dokumen, obeservasi dan FGD.

HASIL DAN PEMBAHASAN

Ilmu Dakwah: Academic Joumal for Homiletic Studies 11(1) (2017) 21-52 
Tari topeng adalah salah satu jenis seni pertunjukan yang telah lama dikenal oleh masyarakat Indonesia. Di Pulau Jawa, topeng tumbuh dan berkembang di pelosok-pelosok Jawa Barat, Jawa Tengah, Jawa Timur, Yogjakarta dan DKI Jakarta. Topeng mencapai bentuknya sebagai seni pertunjukan pada jaman raja-raja Hindu di Jawa diperkirakan abad ke 1011 Masehi (Wahidin, 2006: 14).

Pada awalnya tari topeng memiliki arti tidak hanya sebagai sebuah tontonan atau hiburan, tetapi lebih dari itu memiliki arti keagamaan. Seperti diungkapkan Erika Bourguignon (Wahidin, 2006: 14):

Topeng (kedok) pada mulanya dikenakan untuk menyembunyikan identitas asli pemakainya. Topeng juga sering ditampilkan pada upacara inisiasi anak-anak yang menjelang dewasa. Mereka percaya bahwa roh-roh leluhur dalam wujud orang-orang bertopeng benar-benar datang dan turun ke bumi menemui mereka. Bahkan hingga saat ini, bagi masyarakat tertentu yang masih menganut kepercayaan Indonesia asli, tari topeng dijadikan media upacara adat ritual untuk menghormati nenek moyang. Hal itu, banyak ditemukan dalam upacara adat Ngunjung, yaitu upacara menghormati arwah nenek moyang, dari buyut-buyut atau leluhur di makam mereka yang dikeramatkan.

Tari topeng sendiri diciptakan oleh Sunan Kalijaga putera bupati Tuban, Jawa Timur. Tari topeng kemudian menjadi kesenian yang dipelihara oleh kaum bangsawan di Istana (keraton). Namun, pada saat pusat pemerintahan pindah dari Jawa Timur ke Jawa Tengah dan para raja-raja memeluk agama Islam, sepenuhnya Tari topeng ditinggalkan dan berkembang di lingkungan masyarakat jelata yang belum sepenuhnya melepaskan kepercayaan mereka. Kemudian pada saat Cirebon menjadi pusat penyebaran agama Islam, Sultan Cirebon Syekh Syarif Hidayatullah bersama-sama dengan Sunan Kalijaga dan puteranya Pangeran Penggung mengangkat kembali seni topeng yang saat itu digemari masyarakat, dijadikan sebagai media penerangan dalam penyebaran agama Islam.

Pada prakteknya, Sunan Kalijaga dan Sunan Gunung Jati mempergelarkan Tari Topeng dengan penari seorang Pria yang disebut dalang. Pertunjukkan Tari topeng pada saat itu, tidak bisa dipisahkan dari wayang kulit. Pertunjukan itu sendiri digelar satu hari satu malam dengan dua materi: siang hari untuk tari topeng dan malam hari untuk wayang kulit. Oleh karena itu, dalang memiliki dua profesi siang hari sebagai penari topeng, malam hari sebagai dalang wayang kulit. Namun, seiring perkembangannya dan makin banyak masyarakat tertarik kepada tari 
topeng, maka dalang tari topeng juga diperankan oleh perempuan, bahkan belakangan perempuan lebih banyak menjadi penari topeng.

Tari topeng Cirebon merupakan kesenian asli daerah Cirebon termasuk Indramayu. Jati barang. Majalengka, Losari dan Brebes. Disebut Tari Topeng karena penarinya menggunakan topeng di saat menari. Pada pementasan tari topeng penarinya disebut dalang, karena mereka memainkan peran karakter-karakter dari topeng-topeng tersebut. Tari topeng sendiri banyak ragamnya dan mengalami perkembangan dalam hal gerakan, maupun cerita yang disampaikan. Tari topeng bisa dimainkan sendiri atau bisa juga dimainkan oleh beberapa orang.

Pada zaman dahulu tempat pagelaran tari topeng biasanya di tempat terbuka berbentuk setengah lingkaran, misalnya di halaman rumah, di blandongan atau di bale desa dengan obor sebagai alat penerangan. Namun sekarang sudah mengalami perubahan, tari topeng bisa dipertunjukkan di gedung dengan lampu listrik sebagai tata cahayanya.

Pelaksanaan tari topeng dilakukan dengan beberapa bentuk sesuai dengan tujuan dari masing-masing pertunjukkan tersebut, misalnya: pagelaran komunal: merupakan acara pagelaran yang dilaksanakan untuk kepentingan masyarakat, sehingga seluruh masyarakat di tempat itu berpartsisipasi dalam pagelaran ini, acara yang dipertunjukkan sangat spektakuler dengan adanya arak-arakan dalang, atraksi seni dan lainnya dan digelar lebih dari satu malam, misalnya acara hajatan desa atau acara kepemudaan, pagelaran Individual: acara pagelaran yang diperuntukkan untuk memeriahkan hajatan seseorang, misalnya acara pernikahan, sunatan, kahulan atau melaksanakan nazar, dan pagelaran barengan: merupakan acara pegelaran kelilng kampung yang inisiatifnya datang dari dalang topeng itu sendiri

Berdasarkan jenisnya, pada dasarnya topeng Cirebon dapat ditarikan atau dibawakan oleh beberapa orang, tetapi intinya adalah pertunjukan tunggal, dimana dalang (penari) topeng mengenakan beberapa kedok (topeng) bergantian. Sebagai sebuah pertunjukan teatrikal, topeng sukar dikelompokan. Akan tetapi, berdasarkan cerita Indonesia asli tentang panji, topeng bukanlah suatu tarian drama, tapi juga bukan suatu kesenian abstrak karena terdapat karakter-karakter berbeda yang bisa ditampilkan. Tari topeng Cirebon dapat digolongkan kepada lima karakter pokok yang berbeda yaitu:

1. Topeng Panji. Panji adalah tarian awal dengan mengenakan kedok berwarna putih. Digambarkan sebagai sosok manusia yang baru lahir, penuh dengan kesucian, gerakannya halus dan lembut. Tarian ini bagi 
beberapa pengamat tarian merupakan gabungan dari hakiki gerak dan hakiki diam dalam sebuah filosofi tarian. Iringan musiknya riuh rendah dan berirama cepat. Gerakannya nyaris tak pernah mengangkat kaki, hanya tangan yang nampak bergerak perlahanlahan.

2. Topeng Samba, atau disebut juga pamindo, artinya mindo atau mindua. Tarian ini menggunakan kedok berwarna putih. Tarian ini menggambarkan fase ketika manusia mulai memasuki dunia kanakkanak, digambarkan dengan gerakan yang luwes, lincah dan lucu, suka tertawa dan bermain-main.

3. Topeng Rumyang. Karakter ketiga dengan kedoknya berwarna merah muda sebagai gambaran dari fase kehidupan remaja pada masa akil balig. Watak yang digambarkan periang, ganjen (genit). Dalam tarian rumyang sesekali penari bodor dapat memotong tarian. Dengan gaya humornya ia melontarkan kritikan, dan ketika dalang topeng menantangnya untuk menari yang lebih bagus, dengan seenaknya bodor mengenakan topeng yang salah dan memparodikan tariannya.

4. Topeng Tumenggung, menggunakan kedok berwarna merah gelap kecoklat-coklatan, dengan hidung panjang mata bulat dan gerak tariannya kuat dan tegas. Tarian ini menggambarkan kepribadian bertanggungjawab, rasional dan dewasa, gambaran kedewasaan seorang manusia, penuh dengan kebijaksanaan layaknya sosok prajurit yang tegas, penuh dedikasi, dan loyalitas seperti pahlawan. Tarian ini satu-satunya karakter yang mempunyai cerita/lakon yaitu seorang panglima kepercayaan raja yang diutus untuk menghentikan pemberontakan Jinggananom. Oleh karena itu adegan tumenggung selalu diiringi perang dengan Jinggananom yang mengenakan kedok bodor, lucu.

5. Topeng kelana/ Rahwana merupakan visualisasi dari watak manusia yang serakah, penuh amarah, dan ambisi. Sifat inilah yang merupakan sisi lain dari diri manusia, sisi gelap, yang pasti ada dalam diri manusia. Gerakan topeng kelana begitu tegas, penuh dengan ambisi layaknya sosok raja yang haus ambisi duniawi. Warna kedoknya berwarna merah. Menggambarkan sikap angkara murka, tamak, tidak dapat mengendalikan diri. Tarian ini merupakan tarian yang paling popular dari topeng lainnya, dimana dalang yang menarik sering mendapat saweran dari penontonnya (Hayuning, 2015).

Kelima karakter topeng $\mathrm{di}$ atas dapat dikaitkan dengan pendekatan ajaran agama Islam melalui penjelasan sebagai berikut: 
1. Topeng Panji merupakan akronim dari kata Mapan ning kang siji, artinya tetap kepada satu yang Esa atau dengan kata lain Tiada Tuhan Selain Allah SWT .

2. Topeng Samba berasal dari kata Sambang atau saran yang artinya tetap setia. Maknanya bahwa setiap waktu kita diwajibkan mengerjakan perintah-Nya.

3. Topeng Rumyang. Berasal dari kata Arum/ harum dan Yang / Hyang (Tuhan). Maknanya bahwa kita senantiasa mengharumkan nama Tuhan yaitu dengan do a dan dzikir.

4. Topeng Tumenggung. Memberikan kebaikan kepada sesama manusia saling menghormati, dan senantiasa mengembangkan silih asah, asih dan asuh.

5. Topeng Kelana artinya kembara atau mencari. Bahwa dalam hidup ini manusia wajib berikhtiar.

\section{Tari Topeng sebagai Media Komunikasi Alternatif}

Media adalah sebuah bentuk perantara yang digunakan oleh manusia untuk menyampaikan atau menyebarkan ide, gagasan atau pendapat, sehingga ide, gagasan atau pendapat yang disampaikan itu dapat diterima oleh orang yang dituju (Arsyad, 2002:4).

Sastropoetro (1987:16) menjelaskan bahwa media komunikasi itu dibagi dua golongan yakni media modern dan media tradisional. Adapun yang dimaksud media komunikasi tradisional adalah media yang dipergunakan secara turun temurun oleh nenek moyang manusia diantaranya api, asap, bunyi-bunyian, kentong, tambur, genderang, bedug dan sejenisnya. Sedangkan Effendy (1981: 370) mendefinisikan media tradisional secara khusus adalah media yang dipergunakan oleh khalayak pada masyarakat tertentu secara turun temurun. Penyisipan pesan pada model media komunikasi tradisional sebenarnya hanya sekilas saja, sebab yang paling dominan yang dipertunjukkan adalah lakon dan humornya (hiburannya). Namun, menurut Hidayat (2007:10), nampaknya, komunikasi massa tradisional paling memungkinkan pelaksanaannya untuk daerah pedesaan. Apabila suatu daerah memiliki perkumpulanperkumpulan wayang golek, reog, longser, dongbret dan lainya, hal ini perlu mendapat pembinaan dari instansi-instansi terkait. Melalui perkumpulan-perkumpulan kesenian seperti itulah pesan-pesan tertentu dapat disebarluaskan .

Beberapa jenis kesenian telah dimanfaatkan sebagai media komunikasi alternatif dalam penyebaran Islam (dakwah) di Cirebon pada masa lampau seperti, wayang kulit, gamelan dan tarian. Demikian juga, 
tari topeng sebagai media komunikasi tradisional telah dimanfaatkan untuk penyebaran ajaran Islam (dakwah) baik secara disisipkan maupun secara khusus dalam bentuk cerita atau cuplikan. Cara ini dilakukan oleh para penyebar Islam awal di Cirebon agar masyarakat dapat menerima agama Islam.

Proses Islamisasi di Cirebon dilakukan pertama kali oleh Syekh Datul Kahfi atau Syekh Nurjati pada pertengahan abad ke-14. Syekh Nurjati ketika lahir dikenal dengan panggilan Syekh Datul Kahfi, putera dari syekh Datuk Ahmad, Seorang ulama besar. Syekh Nurjati dikenal sebagai tokoh perintis dakwah Islam di Cirebon. Beliau menggunakan nama Syekh Nurjati pada saat berdakwah di Giri Amparan Jati, yang lebih terkenal dengan sebutan Gunung Jati. Sebuah bukit Kecil dari dua bukit berjarak kira-kira $5 \mathrm{~km}$ sebelah utara Kota Cirebon. Tepatnya di Astana Gunung Jati, kecamatan Gunung Jati, Kabupaten Cirebon (Irianto \& Fatimah, 2009: 11-12)

Syekh Nurjati sendiri lahir di Semenanjung Malaka. Setelah berusia dewasa ia pergi ke Mekkah untuk menuntut ilmu dan berhaji. Kemudian dia pergi ke Bagdad untuk mengamalkan ilmu yang telah diperolehnya. Di Bagdad Syekh Nurjati menikah dengan Syarifah Halimah, puteri dari Syekh Ali Nurdin. Syekh Ali Nurdin putera dari Jamaluddin al- Husein dari Kamboja. Dari pernikahan tersebut dikaruniai empat orang anak: Syekh Abdurakhman (pangeran Panjunan), Syekh Abdurakhim (pangeran kejaksan), Fatimah (yang bergelar Syarifah Bagdad), di Cirebon bergelar Nyi Mas Panatagama Pesambangan dan Syekh Datul Khafid. (Irianto \& Fatimah, 2009: 12-13).

Selanjutnya, Syekh Nurjati diutus Raja Bagdad untuk berdakwah di tanah Jawa. Syekh Nurjati bersama isterinya Syarifah Halimah pergi ke Jawa untuk berdakwah meninggalkan keempat anaknya. Setiba di tanah Jawa Syekh Nurjati mendapat ijin dari Ki Gedeng Tapa untuk bermukim di Pesambangan (di bukit Giri Amparan Jati). Di tempat ini Syekh Nurjati giat berdakwah mengajak masyarakat untuk mengenal dan memeluk Agama Islam. Setelah mengenal tentang agama baru itu, maka berdatangan orang-orang ingin memeluk Islam dan makin hari makin banyak pengikut Syekh Nujati (Irianto \& Fatimah, 2009: 13).

Sepeninggal Syekh Nurjati, penyebaran Islam di Cirebon diteruskan oleh Syarif Hidayatullah. Menurut Buchori dan Kuswilah (2001: 24) pada tahun 1475 M, Syarif Hidayatullah dan Syarifah Muda im sampai di Caruban. Sesampainya di Caruban Syarifah Mudha im meminta izin pada pangeran Cakrabuana untuk tinggal di Pesambangan, di dekat komplek gunung Sembung, tempat dimakamkan 
gurunya Syekh Datul Kahfi (Syekh Nurjati). Peguron Islam Gunung jati peninggalan Syekh Nurjati diteruskan oleh Syarif Hidayatullah. Paguron Islam Gunung Jati ini merupakan pondok pesantren tempat Syarifah Mudha im dan pangeran Cakrabuana menimba ilmu Islam kepada Syekh Datul Kahfi (Syekh Nurjati).

Wildan (2012: 241) menjelaskan masa-masa awal Syarif Hidayatullah di Cirebon:

Dalam tahun-tahun pertama memulai tugas dakwahnya di Cirebon, Sunan Gunung jati berperan sebagai guru agama menggantikan kedudukan Syekh Nurjati dengan mengambil tempat di gunung Sembung, Pesambangan yang agak jauh dari istana atau pusat negeri Cirebon. Setelah beberapa lama bergaul dengan masyarakat ia mendapat gelar/ sebutan Syekh Maulana Jati yang sehari-harinya disebut Maulana Jati. Selain di Dukuh Sembung, ia mengajar pula di Dukuh Babadan, sekitar 3 kilometer dari Pesambangan. Setelah beberapa lama tinggal di Dukuh Sembung, ia memperluas medan dakwahnya hingga ke Banten.

Sepulang dari Banten pada tahun 1949 M, Syarif Hidayatullah naik tahta menggantikan Pangeran Cakrabuana sebagai Sultan pertama di Cirebon dengan gelar Sunan Gunung Jati. Dengan demikian, Syarif Hidayatullah selain menjadi ulama juga sebagai sultan. Syarif Hidayatullah menjadi Nata/ Raja dan Panetep Agama. Setelah di angkat sebagai Sultan di Cirebon gelar Gunung Jati adalah Yang Sinuhun Kanjeng Susuhuan Jati Purba Panetep Panata Agama Aulya Allah Kutubijaman Kholifaturrosulullah S.A.W.

Pada masa Sunan Gunung Jati, Islamisasi di Cirebon sudah berkembang cukup baik berkat dukungan Pangeran Cakrabuna. Pangeran Cakrabuana mendirikan keraton Pakungwati, Keraton yang dipimpin Pangeran Cakrabuana sudah beragama Islam dan meneruskan perjuangan gurunya Syekh Nurjati. Namun, setelah pengangkatan Sunan Gunung Jat, islamisasi di Cirebon Makin kokoh dengan memerdekakan Cirebon dari pengaruh Padjadjaran dan menjadi kesultanan yang merdeka (Sulendraningrat, 1975: 18-19)

Dalam penyebaran Islam di Cirebon, Sunan Gunung Jati melakukan berbagai metode dakwah untuk dapat menarik minat masyarakat masuk Islam, misalnya melalui perdagangan, perkawinan, politik, dakwah dan penaklukan. Secara garis besar, metode dakwah Sunan Gunung Jati dilakukan melalui metode dakwah struktural dan kultural. Secara struktural, Sunan Gunung Jati yang memiliki kedudukan 
sebagai penguasa Cirebon, dan memiliki garis keturuan yang baik dari Ayah maupun Ibunya menyebabkan ia memiliki status sosil yang tinggi, serta memiliki kemapanan secara ekonomi, disamping kesalehan di bidang agama, memudahkan Sunan Gunung Jati untuk memobilisasi masyarakat agar memeluk agama Islam. Penyebaran Islam dengan pendekatan sosial budaya (kultural) telah berhasil melakukan perubahan pada masyarakat setempat, dengan memanfaatkan berbagai media yang secara tradisi telah berkembang di kalangan masyarakat pribumi. Jadi, Dakwah Islam berkembang dengan cara menyebarluaskan pesan-pesan Islamiyah melalu berbagai media yang ada (Ali, 2007: 26)

Menurut Elang Haryanto (Reynaldi, 2014) Sunan Gunung Jati mengajarkan nilai-nilai Islam dengan keberagaman budaya yang ada di Cirebon sebelum Islam masuk. Misalnya, menurut Sunan Gunung Jati ada empat tingkatan Ibadah yaitu: syare at, tarekat, hakekat dan ma rifat. Syare at dilambangkan dengan wayang, yang mana wayang sebagai bentuk perwujudan dari pada manusia dan dalangnya adalah simbol daripada Allah SWT. Tarekat disimbolkan dengan Barong, hakekat disimbolkan dengan Topeng dan ma rifat disimbolkan dengan Ronggeng. Keempat kesenian di atas, mengisyaratkan adanya empat tahapan dalam Islam tadi adalah empat jenis kesenian yang ada di Cirebon.

\section{Revitalisasi Budaya}

Revitalisasi termasuk di dalamnya konservasi-preservasi merupakan bagian dari upaya perancangan kota untuk mempertahankan fisik budaya masa lampau yang memiliki nilai sejarah dan estetika aristektur. Atau revitalisasi juga merupakan upaya pelestarian lingkungan binaan agar tetap pada kondisi aslinya yang ada dan mencegah terjadinya proses kerusakan. Tergantung dari kondisi lingkungan binaan yang akan dilestarikan, maka upaya ini biasanya disertai pula dengan upaya restorasi (pengembalian kepada keadaan semula), rehabilitasi (pemulihan kepada kedudukan yang dahulu), dan rekonstruksi (penyusunan kembali).

Jadi, revitalisasi merupakan upaya memvitalkan kembali suatu kawasan atau bagian kota yang dulunya pernah vital/ hidup akan tetapi kemudian mengalami kemunduran. Selain itu, revitalisasi juga kegiatan memodifikasi suatu lingkungan atau benda cagar budaya untuk pemakaian baru. Bila dikaitkan dengan revitalisasi tari topeng Cirebon, mempunyai arti sebagai upaya melestarikan dan menghidupkan kembali tari topeng sebagai media komunikasi tradisional yang berfungsi sebagai media penyebaran ajaran Islam, atau suatu usaha untuk menghidupkan suatu kekayaan budaya lokal yang mengandung kebijakan hidup. 
Penelitian ini berupaya untuk mengembalikan fungsi, makna dan peran tari topeng di tengah-tengah masyarakat sebagaimana semula, namun karena perubahan zaman, tari topeng juga perlu dikembangkan sesuai dengan tuntutan perkembangan teknologi modern saat ini. Walaupun ada pewarisan budaya dari generasi ke generasi, tidak ada jaminan bahwa budaya lokal akan tetap kukuh terpelihara menghadapi tantangan globalisasi yang menawarkan gaya hidup yang makin pragmatis dan konsumtif.

Revitalisasi sendiri bukannya hanya sesuatu yang berorientasi pada penyelesaian fisik semata, tetapi juga harus dilengkapi dengan peningkatan ekonomi serta pengenalan budaya yang ada. Untuk melaksanakan revitalisasi perlu ada keterlibatan masyarakat. Keterlibatan yang dimaksud bukan hanya ikut serta untuk mendukung aspek formalitas, tetapi keterlibatan yang memerlukan adanya partisipasi masyarakat, selain itu masyarakat yang terlibat tidak hanya di lingkungan masyarakat tertentu, tetapi masyarakat secara luas (Laretna dalam Caray, 2008).

Penelitian ini tidak akan memfokuskan pada upaya revitalisasi secara fisik, dalam pengertian berkaitan dengan penataan tarian atau seni pertunjukannya, melainkan lebih pada pemanfaatan atau fungsi seni pertunjukan untuk kepentingan penyiaran Islam. Sebagaimana dinyatakan di atas, bahwa untuk melaksanakan revitalisasi perlu ada keterlibatan masyarakat. Oleh karena itu, penelitian ini juga mencoba melibatkan partisipasi masyarakat berupa keterlibatan-keterlibatan mereka dalam memberikan gagasan, pemikiran dan solusi-solusi terkait dengan upaya revitalisasi. Namun, keterlibatan masyarakat di sini baru merupakan representasi, terutama pihak-pihak yang terkait dengan kepentingan penelitian ini. Misalnya, representasi dari pemerintah (dinas pariwisata dan kebudayaan), pihak keraton, sejarahwan, seniman, budayawan dan akademisi.

\section{Pemanfaatan Kesenian Tari Topeng Sebagai Media Alternatif dalam Penyebaran Ajaran Islam}

Asal usul tari topeng Cirebon memiliki beragam pandangan baik di kalangan sejarahwan maupun di kalangan masyarakat (Cerita rakyat). $\mathrm{Hal}$ ini dapat dimaklumi, karena di Keraton sendiri tidak memiliki catatancatatan sejarah tentang tari topeng. Begitupun di kalangan masyarakat, saat ini kesenian tari topeng sudah hampir dilupakan Orang. Beberapa 
keterangan yang diperoleh dari hasil wawancara menyatakan beragam pendapat yang berbeda-beda, misalnya:

Elang Mamat dari Keraton Kanoman, menjelaskan bahwa tari topeng Cirebon awalnya dijadikan sebagai media untuk syiar Islam di tanah Jawa, tarian ini terkenal terutama di wilayah Cirebon dan sekitarnya.

Menurut Elang Heri dari Keraton Kasepuhan, Tari topeng Cirebon berkembang sejak abad 15-an, dimana para wali mengemas tari topeng Cirebon sebagai media dakwah Islam yang menceritakan atau menggambarkan 5 karakter (seperti yang telah dikemas oleh para wali) dalam menceritakan proses kehidupan manusia dari mulai lahir hingga ke puncak kejayaan .

Menurut Inu Kertapati (penerus tari daerah) anak dari Surjaatmaja, menjelaskan Pagelaran tari topeng zaman dahulu itu pagelaran berisi seluruh tarian pancawanda. Pagelaran ini berawal bukan untuk menghibur, melainkan untuk mendidik. Secara nilai, kini pagelaran tari topeng sudah bergeser. Tetapi, itu bukan karena keinginan kita selaku budayawan. Melainkan karena faktor keadaan. Pagelaran tari topeng yang dahulu sebagai acara adat, sekarang digunakan sebagai acara ceremonial belaka. Misalnya ketika akan ada acara peresmian apa, kemudian pihak panitia mengundang tari topeng, yang dimainkan tentu salah satunya saja, misalnya rumyang, atau kelana saja, bahkan seringkali dari si pengundang itu meminta pertunjukan dilakukan hanya selama 5 menit saja, atau 10 menit saja, nah di sini penari harus menyesuaikan dengan permintaan tersebut. Hal itu, tidak berarti menghilangkan, tetapi dipotong hanya bagian tertentu saja. jadi seniman sendiri, harus pandai-pandai mengatur gerakan tari yang 5 menit seperti apa, jika dipotong seperti apa .

Tari topeng diciptakan oleh Sunan Kalijaga dan Sunan Gunung Jati. Bagaimana gerakannya, bagaimana kostumnya dan juga maknamaknanya. Setelah itu yang menarikannya Pangeran Panggung. Gamelannya itu dimainkan Pangeran Panjunan dan Pangeran Kejaksan. Tari topeng dijadikan sebagai media syiar agama islam dengan cara Bebarang/ngamen keliling tidak meminta upah, tetapi memakai syahadat. Melalui cara ini memunculkan minat masyarakat kepada tari topeng sekaligus bisa menjadikan media dakwah (Wawancara dengan Inu Kertapati, 14 Juni 2016).

Masih menurut Inu Kertapati, tari topeng itu sebenarnya masih murni. Tidak pernah diubah. Hanya saja disesuaikan dengan keadaan saat ini. Karena aturan tari topeng tidak tertera secara jelas dan gamblang dalam satu naskah. Sebagaimana juga dinyatakan Pangeran Welas bahwa 
tari topeng digunakan untuk mengelabui penjajah. Penari topeng pada masa itu adalah laki-laki, penari topeng perempuan baru ada sekarang. Seni itu sebenarnya dibutuhkan dimana saja dan mempunyai peran penting. Namun, kesenian yang mempunyai tuntunan, mempunyai nilai, dan bisa diresapi tariannya, ada edukasinya, ada tuntunanya, hanya ada dalam seni tradisi. Kalau kita tidak mempunyai pendirian, maka kesenian ini akan tergerus oleh budaya modern. Budaya luar atau budaya barat, seringkali tidak bisa dikontrol, berbeda dengan tarian tradisional, ada aturan-aturan etika kesopanan, misalnya pada tari topeng, ada aturan sebelum pertunjukan harus dilakukan sembah dulu, tidak boleh vulgar gerakannya, kostumnya tidak menggugah syahwat dan tidak terlihat lekukan badan (Wawancara dengan Inu Kertapati, 14 Juni 2016).

Sementara Nur Annani (penerus sanggar Purwa Kencana) Losari menyatakan:

Kalau kita berbicara tentang sejarah tari topeng Losari kita juga harus berbicara banyak hal tentang Cirebon, tari topeng Cirebon itu ada banyak dan beragam gaya: gaya Slangit, gaya Palimanan, gaya Kroya, gaya Beber, gaya Indramayu, gaya Gegesik, gaya Majalengka dan Losari. Gaya Losari adalah satu-satunya gaya yang berbeda di wilayah Timur. Itu kalau kita berbicara tentang Cirebon. Kalau kita berbicara wilayah Cirebon Barat seperti: Gegesik, Palimanan, Indramayu, Kroya, dan Beber (Wawacara dengan Nur Annani, 18 Juni 2016).

Tari topeng pada masanya dipergunakan sebagai media syiar Islam oleh Sunan Kalijaga, itu sebabnya tari topeng Cirebon pada umumnya baik itu di Losari, di Kalianya, di Gegesik, di Palimanan, di sana dalang topeng atau penarinya percaya bahwa tari topeng yang menciptakannya sunan kalijaga, tetapi dari Losari tari topeng disempurnakan oleh Panembahan Losari atau Raden Angkawijaya atau Pangeran Losari. Beliau adalah Cucu Suanan Gunung Jati yang makamnya saat ini berada di makam Pasarean Losari Jawa Tengah, setelah jembatan Cisanggarung (Wawacara dengan Nur Annani, 18 Juni 2016).

Suatu saat Sunan Kalijaga nopeng di suatu tempat. Orang-orang hanya bisa mendengar gamelannya saja, tanpa melihat siapa yang memainkannya dan siapa yang menarikannya. Ia kemudian berseru kepada orang yang berkumpul di sekitar datangnya bunyi gamelan itu, bahwa jika ingin melihat para penabuh yang memainkan gamelan dan yang menari, maka masing-masing harus mempunyai tiket yakni dengan mengucapkan dua kalimat syahadat, ketika dua kalimat 
syahadat diucapkan, maka seketika itu juga pertunjukkan topeng tampak (Suanda, 2009).

Di lingkungan seniman topeng dan wayang kulit Cirebon, tokoh Sunan Kalijaga dan Sunan Panggung amat dihormati dan dimitoskan sebagai leluhur kedua seniman itu. Penghormatan atas kedua tokoh itu seringkali terucapkan dalam do a manakala mereka akan mulai pentas. Namun, kesenian tradisional Indonesia yang telah tumbuh dan berkembang sejak abad ke 10 s.d. abad ke $11 \mathrm{M}$, pada saat Cirebon menjadi pusat pengembangan syiar agama Islam, Sunan Gunung Jati bersama dengan Sunan Kalijaga, mengangkat kesenian wayang dan tari topeng menjadi tontonan di keraton yang juga berfungsi sebagai tuntunan dalam penyebaran Islam (Dahuri et al., 2004: 127).

Cara memadukan antara unsur kesenian dan unsur dakwah dalam tari topeng, menurut Elang Mamat:

Dakwah itu bukan hanya dengan bicara, tetapi bisa juga dengan gerak, jadi, tarian itu juga dakwah. Tergantung bagaimana kita mau menyampaikan dakwah itu. Pada awalnya tari topeng dapat dijadikan sebagai media dakwah, bermula dari mereka (masyarakat) tertarik dengan tari topeng, bahkan banyak orangorang yang penasaran dengan tari topeng, sehingga banyak diantara mereka yang bertanya tentang tari topeng. Nah pada saat itu kita akan menjelaskan apa itu tari topeng, dengan satu syarat yaitu harus mengucapkan dua kalimat syahadat, artinya mereka harus masuk Islam dulu. Hal itu syarat untuk mengetahui makna apa yang terkandung didalam gerakan tari topeng.

Dengan begitu, ada sesuatu yang tidak bisa dipaksakan dalam penyebaran agama Islam, hanya orang-orang yang penasaran dan ingin tahu dan memiliki ketertarikan dengan tari topeng dan ahirnya mereka mau mengikuti persyaratan yaitu ada salah satu persyaratan yang memang harus mereka lakukan dengan mengucapkan dua kalimat syahadat. Setelah Islam, baru mereka tahu tentang makna-makna kehidupan yang diperankan dalam tarian topeng, seperti yang ada di pesantren-pesantren. Tetapi, geraka-gerakan yang ada di tari topeng ini merupakan simbol-simbol yang mereka harus patuhi, seperti gerakan sholat, ada juga gerakan sedang berwudlu. Artinya kita yang akan mendirikan shoalt itu wajib terlebih dahulu berwudlu. Kalau dia tidak mau memenuhi persyaratan tersebut seperti mengucapkan dua kalimat syahadat, ya tidak apa-apa, berarti dia tidak akan mendapatkan ilmu tentang makna-makna yang ada dalam tari topeng tersebut (Wawancara dengan Elang Mamat, 6 Juni 1016). 
Setiap tarian yang ditampilkan memiliki pesan-pesan atau lakon cerita secara berbeda-beda. Dalam sebuah tarian, pesan atau lakon cerita dipresentasikan dalam bentuk gerakan. Setiap gerakan tarian memiliki makna yang berbeda-beda dan secara otomatis ingin menyampaikan pesan-pesan berbeda-beda pula. Penentuan lakon yang berbeda-beda itu tergantung dari dalang (penari topeng), topeng itu tidak selamanya baku gerakannya seperti itu, bisa berubah saat dalang (penari) mau melakonkan tentang apa. Misalnya, pada topeng panji, ia melakonkan sosok orang yang senang bershodaqoh, gerakannya pun akan lebih banyak melakonkan simbol-simbol bagaimana orang yang senang bershodaqoh. Topeng klana, menyimbolkan angkara murkanya manusia, itulah nafsunya manusia. Tetapi, dalam Islam nafsu itu tidak semuanya buruk nafsu, itukan dibagi-bagi, nafsu yang mana yang kita akan lakukan (perankan) (Waw ancara dengan Elang Heri).

Setiap pertunjukan tari topeng melibatkan beberapa orang: dalang (penari topeng), pelaku gamelan, topeng, dan pemain peralatan musik. Ada ritual tertentu yang harus dilakukan oleh penari topeng sebelum pertunjukkan dimulai. Biasanya yang dilakukan penari topeng sebelum pertunjukan yaitu puasa, karena dengan puasa itu nafsu kita dikekang dan juga dengan puasa itu bisa menundukan dua aspek, yaitu nafsu perut dan mata.

\section{Makna Simbolis Dalam Kesenian Tari Topeng Cirebon}

Menurut Elang Heri Hadiningrum, topeng dalam arti yang sempit adalah penutup muka. Arti tersebut sekaligus menunjukkan fungsi yang sempit pula. Adapun fungsi topeng secara luas berkaitan dengan berbagai kepentingan manusia dalam kehidupan. Ia bisa berfungsi sebagai hiasan, souvenir, dan sebagainya. Dalam kehidupan sehari hari topeng (bukan dalam arti benda seni) dapat dipergunakan untuk berbagai kepentingan, misalnya sebagai pelindung, keamanan, kesehatan, mainan dan sebagainya. Sebaliknya, jika dikaitkan dengan kesenian, topeng biasanya dipergunakan untuk berbagai kepentingan menari, bermain teater, film dan pertunjukkan lainnya. Topeng juga tidak hanya dipakai oleh manusia untuk berbagai kepentingannya, namun sering juga dipakaikan pada binatang kera dalam pertunjukan topeng monyet misalnya (Wawancara dengan Elang Heri).

Kata Topeng di daerah Cirebon, dan sekitarnya terutama di daerah pantai utara Jawa Barat memiliki konotasi yang beragam makna semantiknya. Kata topeng bagi masyarakat Cirebon bukanlah sebagai sebuah benda sebagai penutup muka, melainkan menunjukkan berbagai 
identitas. Secara leksikal topeng memang bermakna sebagai penutup muka, sebagaimana dipakai dalam kamus bahasa Indonesia dengan istilah kedok. Namun, paling tidak, topeng memiliki dua pengertian. Pertama, berarti sebagai pertunjukkan tari-tarian yang menggunakan kedok (Panji, Pamindo/Samba, Rumyang, Tumenggung dan Klana) dan berlatar belakang cerita panji. Artinya, pertunjukkan topeng yang tidak berlatar belakang cerita Panji, tidak lazim disebut topeng, karena pertunjukkan seperti itu biasanya mempunyai nama masing-masing misalnya wayang wong kedok atau berokan. Kedua, artinya sama dengan penari, jika kata itu diikuti dengan nama orang, misalnya topeng Rasinah, topeng Sujana dan lain-lain.

Tari topeng Cirebon memiliki 5 karakter, seperti yang telah dikemas oleh para wali dalam menceritakan proses kehidupan manusia dari lahir hingga ke puncak kejayaan. Yang pertama, Panji menggambarkan kesucian. Artinya bahwa ia baru mengenal dunia atau ia masih sosok yang polos atau suci.Yang kedua, Samba atau pamindo menggambarkan orang yang berikhtiar, banyak belajar tentang kehidupan dunia. Yang ketiga, Rumyang menggambarkan sosok sifat yang labil, masih belum bisa meyakini atau belum bisa menentukan pilihan atau masih dalam masa transisi.Y ang keempat, Tumenggung menggambarkan sosok yang telah mapan. Telah mengetahui mana yang baik dan yang buruk sehingga ia sudah menjadi bijak serta telah patuh kepada pemimpinnya. Makanya dalam kepemimpinan ia digambarkan menjadi sebagai wakil dari raja. Yang kelima, yaitu Klana menggambarkan angkara murka, inilah puncak symbol kehidupan yang digambarkan sebagai angkara murka. Karena biasanya titik puncak kehidupan manusia itu masa kejayaan, yaitu tercapainya cita-cita. Yang ter terbaik, terkaya, terpandai, terkuasa dan lain sebagainya, hal itu akan dekat dengan angkara murka. Sedikit meleset saja, maka akan lari keangkara murka, seperti menjadi sombong. Itu semua menjadi rambu-rambu kita atas tuntunan dari filosofi topeng itu sendiri (Wawancara dengan Elang Heri, 6 Juni 2016).

Sementara bu Nur Annani (mbak Nani), menjelaskan tentang makna filosofi yang terkandung dalam tari topeng:

Di wilayah barat (cirebon bagian barat) mereka cenderung menganggap tari topeng itu lebih kearah filosofi, tetapi topeng losari lebih kepenokohan. Oleh karena itu, topeng Losari dan topeng Cirebon secara histori, koreografi gerak dan penyajian, musik, kostum, dan ritual itu berbeda dengan tari topeng yang ada di wilayah barat. Secara garis besar, topeng Losari itu lebih 
mengedepankan kepada ritual dan berdoa. Jadi, menari bukan hanya membawakan karakter sebuah pertarian, tetapi lebih kepada pendekatan diri antara si penari dengan Tuhannya. Komunikasi penari dengan Tuhannya Itu ada dalam topeng Losari. Tetapi, kalau di topeng Cirebon lebih kearah filosofi. Menggambarkan tentang karakter manusia, penggambaran watak manusia misalkan panji bayi yang baru lahir, samba dan seterusnya. Tetapi tari topeng Losari lebih kearah penokohan, selain itu, tarian dianggap sebagai ritual pendekatan diri antara penari dengan Tuhannya itu sebabnya tari topeng tidak pernah meninggalkan yang namanya ritual dan pakem (Wawancara dengan bu Nur Annani, 18 Juni 16.30).

Topeng Losari selalu mempunyai pakem (aturan etika), seperti: penari tidak boleh menari membelakangi kotak topeng atau nayaga atau pangrawih, karena kami percaya bahwa disitu ada 9 wali yang berada diantara nayaga. Kami juga percaya bahwa sebelum menari dan sesudahnya ada istilah ritual nyambat. Ritual nyambat itu memanggil energi lain dimasukkan ke tubuh kemudian menggantikan dengan energi lain (Wawancara dengan bu Nur Annani, 18 Juni 16.30).

Adapun pokok-pokok yang terdapat dalam tari topeng Cirebon ada 9 Gerakan: Adeg-adeg, pasangan, Capang, Bantingan Tangan, Jangkung Ilo, Godeg, Gendut, Kenyut danLO Nindak/ nyandak. Kesembilan gerakan tersebut merepresentasikan 9 lubang yang terdapat dalam tubuh manusia. Dua lubang hidung, dua lubang telinga, dua lubng mata, dua lubang pelepasan (depan belakang), dan satu lubang mulut. Sedangkan makna dari kesembilan gerakan tersebut yaitu: 1) Adeg-adeg: artinya kita harus berdiri kokoh agar tidak tergoyahkan. 2) Pasangan: artinya kita senantiasa memberi suri tauladan kepada orang lain dengan berbuat kebajikan dan kebaikan. 3) Capang: artinya kita senantiasa memberikan pertolongan atau ringan tangan. 4) Bantingan tangan: artinya kita harus senantiasa bekerja keras. 5) Jangkung Ilo: artinya kita mengukur keinginan dengan kemampuan yang ada. 6) Godeg: artinya geleng kepala, maknanya apabila kita melihat saudara kita sesama manusia yang sedang dilanda kesusahan kita senantiasa menggelengkan kepala (menengok kiri kanan) dan kemudian menolongnya sesuai kemampuan. 7) Gendut: artinya, dalam hidup kita jangan gemuk sendiri, karena masih banyak saudara kita yang kekurangan dan hidup dibawah garis kemskinan. 8) Kenyut: artinya kepincut, maknanya harus kepincup kepada hal-hal yang sifatnya positif dan konstruktif. 9) Nindak/Nyangka: 
artinya bertindak atau berbuat, maknanya kita senantiasa harus berbuat atau bertindak menuju jalan yang diridhoi Allah SWT.

Sedangkan Elang Heri (Hasil Wawancara dengan Eang Heri, 6 Juni 2016) menjelaskan beberapa makna dari gerakan tari topeng agak berbeda dari pejelasan di atas. Misalnya Buang rawih, menandakan kita harus mendengar nasehat-nasehat dari siapapun tidak terkecuali. Kemudian memasukkan kedalam hati dan jika terdengar kurang baik, maka buang kembali. Jangkung ngilo, jangkung ngilo itu kakinya ngangkat satu, dan matanya melihat ke bawah. Maksdunya pada saat kita berkuasa jangan sombong cobalah melihat ke bawah, atau intinya instrospeksi diri. Tertawa, itu simbol bahwa kita jangan suka menertawakan orang lain, lebih baik kita menertawakan diri kita sendiri. Buang soder, maknanya kita membuang yang kurang baik untuk diri kita. Adeg, itu menandakan pondasi kita, pondasi kita itulah Agama. Gedig, menjalani hidup itu harus yakin. Kenyut, menjalani hidup itu dengan hati-hati

Selain tarian-tarian memiliki makna tertentu, pakaian yang dipakai oleh penari topeng memiliki makna-makna, berikut petikan pernyataan Elang Heri,:

Secara kasat mata, makna-makna itu melambangkan perpaduan, artinya kita saling menghormati satu sama lain. Menghormati kepada orang-orang dengan latar belakang daerah yang bermacam-macam, dengan kepercayaan agama yang berbeda-beda dan sebagainya. Hal itu disimbolkan dalam desain. Desain-desain interior itu menerangkan simbol-simbol dari berbagai daerah. Seperti india yaitu hindunya, dari china budhanya, dengan adanya subra di ikat kepala. Kalau dari Islamnya itu ada rawis, yang melambangkan tasbih. Semuanya menyatu dan saling menghargai dan menghormati (Hasil Wawancara dengan Eang Heri, 6 Juni 2016).

Beberapa perlengkapan yang digunakan dalam pertunjukkan tari topeng Cirebon adalah: Kedok (topeng) terbuat dari kayu dan cara memakainya dengan menggigit batalan karet pada bagian dalamnya, Sobra sebagai penutup kepala yang dilegkapi dengan jamangan dan dua buah Sumping, Baju yang berlengan, Dasi yang dilengkapi dengan peniti ukon (mata uang jaman dulu), Mongkron yang terbuat dari batik lokoan, Ikat pinggang Stagen yang dilengkapi badong, Celana sebatas bawah lutut, Sampur/ Selendang, Gelang tangan, Keris, Kaos kaki putih sampai lutut, Kain batik, Kadang-kadang dilengkapi dengan boro (epek).

Selain kelengkapan di atas, kadang-kadang untuk tari topeng tumenggung dilengkapi dengan tambahan tutup kepala kain ikat, peci dan kaca mata. Makna-makna dari atribut yang dipergunakan dalam 
pertunjukan tari topeng juga menggambarkan nilai-nilai luhur seperti: Sobra itu maknanya harus sabar, hal itu karena untuk mendinginkan kepala, Rawih, agar selalu bertasbih, Kerodong, yaitu sebuah sorban bentuk kesucian, Kain yang tinggi dan membuka kain artinya yang baik kita sebarkan dan yang jelek kita hilangkan.

Berdasarkan makna-makna simbolis yang telah digambarkan di atas, jelas tari topeng memiliki kekayaan makna dalam bentuk karakter, sikap dan perilaku luhur terutama terkait dengan nilai-ilai moral yang menjadi muatan untuk berdakwah. Seperti dijelaskan Elang Panji:

Bahwa tari topeng itu dijadikan sebagai hiburan dan tuntunan yang telah diterima oleh masyarakat. Para wali dalam mengembangkan itu tidak dengan memaksa masyarakat untuk masuk Islam, namun secara halus. Pembuktiannya adalah seperti itu, yaitu mengikuti arus-arus yang berkembang di masyarakat, dengan mensiasati atau membentuk (membungkus) lagi dengan misi-misi keIslaman. Contoh lain seperti wayang, tokoh-tokoh perwayangan mahabarata itu berasal dari hindu, dan oleh para wali dikemas dengan symbol-simbol Islam. Itulah cara penyampaian dakwah mereka, memanfaatkan media-media yang berkembang di masyarakat, dijadikan sebagai salah satu media dakwah alternatif.

Bagi masyarakat sendiri, untuk memahami makna-makna yang terkandung dalam tari topeng, bisa dilakukan dengan cara memaknai symbol-simbol yang ada, lalu dijadikan sebagai panutan. Artinya penonton bisa memaknai tentang hidup itu seperti digambarkan dalam lakon tarian ini, minimalnya mereka menyadari ada barometer untuk diri kita sendiri. contohnya di masa labil, bagaimana kita menghadapi masalah di usia yang labil, maka bisa dilihat dari pertunjukan tari topeng, atau juga saat telah merasa puas, telah mencapai cita-cita dan ketika kita sudah menjadi orang terkaya, terhebat dan lainnya. Ingatlah dengan panutan-panutan itu, sehingga kita hati-hati saat telah mencapi semua itu tidak sembarangan, menjadikan kita tidak akan meremehkan orang lain. Semua tuntunan-tuntunan itu memang bersifat abstrak, tetapi dapat dimaknai dan diterapkan dalam kehidupan nyata. Artinya, meskipun penggambarannya abstrak, namun maknanya nyata (Wawancara dengan Nur Annano, 18 Juni 2016).

Namun, berbeda dengan pendapat Nur Annani Penonton belum tentu paham makna yang disajikan dalam tarian, karena biasanya mereka hanya menjadi penikmat.

Kadang-kadang mereka tidak berpikir ini maknanya apa sih atau ini tentang apa sih, mereka cuma nonton kemudian 
selesai, hanya ada beberapa orang yang kritis mencoba ingin tahu makna dari tarian itu. Artinya, punya makna atau tidak suatu tarian yang disampaikan, itu juga hanya ada pada orang-orang yang cerdas biasanya yang berfikir begitu. Tetapi, bagi orangorang awam biasanya mereka hanya mengapresiasi, terus pulang, selesai. Mereka, hanya melihat sebuah ketertarikan masyarakat secara umum terhadap kesenian, misalnya dengan berkomentar: wah hebat, wah..bisa galeong sampai bawah, atau menarinya bagus ya.., wah..topengnya nempel. Tetapi, kalau kita mementaskan sesuatu di lingkungan Akademisi (PT), atau di depan budayawan-budayawan, seniman-seniman, dimana mereka secara pemikiran itu sangat kritis, mereka pasti berpikir makna apa yang disampaikan penarinya untuk kita yang menonton biasanya begitu (Wawancara dengan Nur Annano, 18 Juni 2016).

Oleh karena pentingnya menyebarkan nilai-nilai moral yang terkandung dalam tarian itu, maka berbagai strategi dilakukan oleh para penari tari topeng dalam rangka menarik minat penonton untuk terlibat dalam alur cerita yang disajikan. Misalnya, dengan cara mengemas dengan baik pertunjukkan yang akan ditampilkan, Penari harus menarikan tarian secara baik/luwes, penyajian yang baik tentu saja ada tatakramanya, juga dilakukan dengan konsentrasi penuh. Yang terpenting dalam melakukan segala sesuatunya harus serius. Sehingga memperoleh hasil secara maksimal (Wawancara dengan Nur Annano, 18 Juni 2016).

Penari topeng dapat memahami bahwa sajian yang ditampilkan sudah berhasil menarik penonton adalah dengan melihat dari tanggapan para penontonnya sendiri, mungkin dari tepuk tangannya, atau ucapan selamatnya, atau pertanyaan-pertanyaan lain yang disampaikan audiens. Perhatian yang ditunjukkan itu menandakan bahwa penonton respek dengan apa yang mereka saksikan, dan pada gilirannya semua ini akan berdampak pada perhatian penari sendiri terhadap mereka dengan terus berusaha memenuhi harapan public. Yang menjadi ukuran kepuasan bagi penari topeng setelah menampilkan pertunjukannya adalah kesungguhan penampilan, karena setiap penari tujuannya satu yaitu tampil dengan sukses. Meskipun kepuasannya itu sendiri relative sifatnya. Ada seniman tari yang merasa puas karena pertunjukkan tariannya telah sesuai dengan tujuannya, atau karena kebolehannya, dakwahnya, keberaniannya ataupun hiburannya. Jadi kepuasan bagi setiap seniman tari itu sangat relative.

Dalam tari topeng ada istilah penari topeng dan ada dalang. Selama ini beberapa orang menyamakan istilah dalang dengan penari topeng. Hal ini sebagaimana banyak di tulis orang bahwa pada jaman 
dulu pertunjukan wayang dan tari topeng itu disatukan dan dilaksanakan sehari semalam, Siangnya diselenggarana pementasan tari topeng dan malam harinya diselenggarakan wayang kulit. Karena itu, dalang dan penari itu sama dilakukan oleh satu orang laki-laki. Menurut Nur Annani, dalang dan topeng itu berbeda:

Nah ini, yang harus kita pahami bahwa dalang topeng itu berbeda dengan penari topeng. Dalang topeng itu dedengkotnya, karena untuk menjadi dalang topeng itu harus melalui beberapa fase ritual yang tidak dilakuakan oleh penari penari pada umumnya. Biasanya berperan pada saat masa ahir menjelang pertunjukkan awal dan ahir biasanya kalau di topeng Losari.

Dalam pementasan seni tari topeng terdapat seperangkat instrumen, jika seandainya dirubah misalnya rawih atau musiknya tidak memakai gamelan, hal itu tidak akan kehilangan ciri khas dari topeng itu sendiri. itu hanya persoalan teknis tidak akan berpengaruh apapun, tetapi untuk si pelaku dalang topeng itu sendiri sangat berpengaruh hebat karena ketika menari dengan kaset dan menari dengan gamelan yang jelas energinya lebih bagus itu ketika di iringi oleh gamelan langsung ketimbang dengan kaset (Wawancara dengan Nur Annani, 18 Juni 2016).

\section{Upaya Revitalisasi Kesenian Tari Topeng Cirebon}

Sebagaimana telah dipaparkan di atas, bahwa seni pertunjukkan tari topeng mengandung makna-makna luhur yang selaras dengan ajaran Islam. Karena hasil kreasi dan disebarkan oleh penyebar ajaran Islam di tanah Jawa (Wali), ia bisa dikemas dan ditampilkan melalui alat-alat atau media yang menyenangkan dan mudah untuk diterima semua kalangan. Tari topeng memegang peranan penting pada masa-masa awal penyebaran Islam di Jawa Barat.

Agama Islam disebarkan oleh para wali dengan jalan halus (tanpa kekerasan). Dengan kata lain agama Islam masuk ke tanah Jawa dengan jalan damai. Sikap para wali dalam melaksanakan syiar Islam menjadi panutan bagi masyarakat pada masa kini. Islam diterima oleh masyarakat atas dasar kesadaran bukan karena paksaan. Karena itu, menjadi penting saat ini, tradisi dan metode penyebaran Islam dengan memnfaatkan seni pertunjukkan tradisional terus direvitalisasi, dengan penyesuaian di sana sini agar tidak termakan arus jaman.

Revitalisasi adalah upaya melestarikan dan menghidupkan kembali tari topeng sebagai media komunikasi tradisional yang berfungsi sebagai media penyebaran ajaran Islam, atau suatu usaha untuk menghidupkan 
suatu kekayaan budaya lokal yang mengandung kebijakan hidup. Untuk melaksanakan revitalisasi perlu ada keterlibatan masyarakat.

Uuk Sukarna (Sie kebudayaan dan kesenian) kabupaten Cirebon menjelaskan bahwa pemerintah kabupaten Cirebon dalam hal ini dinas kebudayaan dan pariwisata (kebudpar) sudah melakukan langkah-langkah revitalisasi. Dengan beberapa cara antara lain: Pertama, melakukan pasanggiri tari topeng tingkat kabupaten Cirebon, kegiatan itu ditujukan untuk pelajar pada tahun 2011. Yang dipasanggirikan atau diperlombakan semua gaya tari topeng yang ada di Cirebon, seperti gaya Losari, gaya Selangit, gaya Palimanan, gaya Gegesik dan gaya Kalianyar. Sementara ini yang baru dilombakan baru dua wanda yaitu wanda samba dan wanda kelana. Kedua, pemerintah daerah juga sudah melakukan pewarisan. Pewarisan itu dimana para pelakunya yaitu para sesepuh-sesepuh tari topeng yang mewariskan kepada yang muda-muda. Jadi, regenerasi di Cirebon ini sudah tidak mengkhawatirkan lagi. Yang mengkhawatirkan di Cirebon ini nayaganya, para pemain musiknya. Oleh karena itu, kami (Sie kebudayaan Curebon) juga sudah melakukan pewarisan untuk nayaga terutama pemain kendang, dengan upaya itu, kini daerah Cirebon sudah memiliki pemain nayaga bahkan anak-anak (pemain kendang junior). Yang perempuan juga ada, jadi, dalam upaya untuk merevitalisasi tari topeng tinggal nanti kedepan kita melakukan istilahnya mulasara, yaitu memelihara. Tahun depan pemerintah mulasara tari topeng Losari, kemudian baru gaya-gaya yang lain. Tentu saja upaya ini akan dilakukan secara bertahap, karena anggaran pemerintah yang tersedia untuk itu juga terbatas. Bentuk upaya pelestarian itu bagi pemerintah sudah terprogram, tinggal menunggu upaya-upaya apa yang akan dilakukan oleh kalangan seninam termasuk dari masyarakat sendiri (Wawancara dengan Uuk Sukanda, oktober 2016).

Pemerintah daerah kabupaten Cirebon dapat memanfaatkan kesenian tari topeng sebagai media alternative untuk komunikasi sosial, tetapi itu dilakukan dengan sangat hati-hati, jangan sampai unsur seni aslinya hilang. Sebagaimana dijelaskan Uuk sebagai berikut:

Ya jadi sebetulnya bukan hanya tari topeng saja, banyak dari kesenian lain dan kami juga dengan teman-teman dari FKMETRA (forum komunikasi media tradisional) kami sudah melakukan upaya-upaya untuk bagaimana seni ini, karena seni juga seperti yang diketahui bahwa keberadaan seni tari topeng itu ada tiga fungsi, artinya dalam bahasa seninya yaitu Trismara Bhakti tiga fungsi kesenian, yaitu kesenian sebagai media pendidikan, kesenian sebagai media penyampaian pesan 
(informasi), dan kesenian sebagai media hiburan. Jadi ketiganya harus imbang. Hal itu telah dimanfaatkan oleh pemerintah kabupaten Cirebon, tetapi dengan catatan dalam pesan-pesan ini kita juga jangan sampai merusak seninya. Artinya, misalkan dalam tari topeng, pengen memperluas isi pesannya boleh saja, asalkan pesan-pesan khususnya tentang kehidupan dari perjalanan hidup manusia mulai lahir sampai dewasa itu tidak boleh hilang di tari topeng.

Kehati-hatian juga dilakukan pemerintah dalam memanfaatkan kesenian tari topeng sebagai media dalam penyampaian pesan-pesan pembangunan, terutama pembangunan mental spiritual, sebagaimana dinyatakan Uuk:

Pemerintah dalam menyampaikan pesan-pesan pembangunan dilakukan dengan secara terselubung, artinya secara tidak blakblakan karena kalau kita blak-blakan dalam penyampaian pesan, maka secara otomatis mereka akan menolak. Jadi, kami sebagai dinas yang membina masalah teknis seni itu sangat keberatan kalau ada terang-terangan, misalnya dalam pergelaran wayang kita bicara KB, masa iya secara terang-terang, jadi melalui simbolsimbol dalam bahasa wayangnya, bahasa seninya. Jadi kita didalam kesenian itu tidak terang-terangan misalkan mau menyampaikan pesan apa, pesan pemerintah atau misalkan ada pesan dari dinas-dinas lain yang di titip pesan melalui seni pertunjukan yaitu nanti diolah lagi oleh para seniaman, karena seniman sudah jagonya mengemas bagaimana menyampaikan pesan kepada masyarakat, melalui seni.

Fungsi seni seperti yang sudah dijelaskan, (sebagai media hiburan, pendidikan dan informasi), telah dibawakan oleh leluhur kita, pencipta seni tari topeng cirebon yaitu kanjeng Sunan Kalijaga, cara beliau dulu mengislamkan orang itu dengan tidak dipaksa, dan sangat hati-hati, disampaikan melalui simbol-simbol, contohnya ketika Sunan Kalijaga menyampaikan pesan tentang kuku pancanaka miliknya Bima itu, apa maknanya?, kenapa kukunya tajam?, panca itu artinya lima, naka itu artinya waktu, Jadi, melalui simbol-simbol itu Sunan Kalijaga ingin menyampaikan pesan bahwa kita senantiasa harus mengingat lima waktu untuk sholat. Kemudian, Jimat layang kalimatsada. Jimat itu apa?, Jimat itu artinya siji kang dirumat, atau satu yang dipelihara, sedangkan yang dimaksud kalimatsada yaitu dua kalimat syahadat. Maknanya bahwa sebagai umat Islam, kita harus mengakui keyakinan tentang Allah sebagai 
Tuhan, dan nabi Muhammad sebagai Rosul Allah. Demikian juga dengan symbol-simbol dalam tari topeng, misalnya, adeg-adeg itu maknanya bahwa kita itu harus kuwat pondasinya, jangkung ngilo di topeng itu maksudnya, kalau sudah tinggi seseorang kedudukannya jangan sombong, bendu, maknanya bahwa kita jangan kenyang sendiri. Banyak sekali pesan pesan yang disampaikan memiliki nilai dakwah islam, tinggal bagaimana penonton itu mampu mencermatinya.

Strategi pemerintah agar tari topeng tidak hanya menjadi kesenian daerah yang hanya diminati oleh masyarakat lokal, tetapi juga diminati oleh wisatawan luar. Menurut Uuk caranya dengan mengemas bagaimana seni itu tidak membosankan, tetapi tetap menarik untuk semua kalangan. tetapi jangan sampai tari topeng dicampuri misalnya musiknya hip-pop. Musiknya tidak dirubah, gerakan-gerakannya tidak keluar dari pakem, tetapi kemasannya seperti: penampilan, pakaian nayaganya seragam, lighting, durasinya, dan lainnya, bisa berubah.

Nur-Annani memiliki pandangan yang berbeda tentang upaya pemerintah dalam melakukan revitalisasi kesenian tari topeng: Menurutnya, Ada sisi positifnya dan ada sisi negatifnya. Itu tergantung siapa yang sedang duduk di sana. Karena perperiode pasti berbeda yang duduk (ngejabat) berbeda juga kebijakannya. Sejatinya, pemerintah memandang seniman itu sama rata, mereka mempunyai hak yang sama untuk dipromosikan, eksistensi mereka butuh pengakuan dari siapapun. Termasuk budpar. Sejauh ini peran budpar untuk pengembangan topeng Losari cukup bagus, misalnya, seniman Losari pernah diberikan pelatihan tari topeng Losari, diberikan pelatihan revitalisasi tari topeng. Tetapi, hal itu menurut saya belum cukup, ada saatnya seniman itu ingin dilibatkan dalam acara-acara kepemerintahan, pada momen-momen tertentu, meskipun hanya sesekali. Tetapi, melihat realitas seperti itu, kita sebagai seniman jangan terlalu berharap penuh kepada pemerintah, karena akan mati. Seorang seniman harus mempunyai prinsip bahwa kita harus bisa menjemput bola jangan menunggu bola, kalau seniman menunggu bola, matilah dia. Jadilah seniman yang bisa menjemput bola artinya kita melakukan banyak cara bagaimana supaya kita bisa pentas di luar Cirebon misalnya (Wawancara dengan Uuk Sukanda, oktober 2016).

Untuk menuju ke arah sana banyak faktor yang mendukung, salah satu faktor yang paling utama adalah masyarakat dan pemerintah. Peran pemerintah justru yang diharapkan oleh para seniman. Karena suatu kesenian atau komunitas itu tidak akan pernah hidup atau eksistensinya diakui secara luas, tanpa peran masyarakat dan pemerintah. Jadi, seniman itu tidak akan menjadi apapun, siapapun tanpa bantuan masyarakat dan 
pemerintah, meskipun kita tidak sepenuhnya berharap kepada pemerintah, tetapi minimal ada pengakuan dari mereka, ada penghargaan dari mereka.

Selain, pemerintah pihak lain yang memiliki konsen untuk pengembangan dan pelestarian tari topeng adalah kalangan keraton sendiri. Karena keraton merupakan pusat budaya, terutama yang kental dengn nuansa Islamnya. Strategi yang dilakukan pihak keraton untuk melestarikan kesenian tari topeng misalnya, mereka mengadakan banyak kegiatan, membuat agenda-agenda budaya contohnya, tahun lalu, diadakan kegiatannya di Sunyaragi, dengan tema panggung budaya . Cara lain pernah di lakukan oleh keraton untuk merevitalisasi tari topeng adalah memanggil guru untuk mengajari putera dan puteri keraton. Sebagaimana dijelaskan Bambang:

Waktu saya kecil, waktu ibu saya kecil dan penghuni-penghuni keraton dulu, saya tanya ana topeng beli bu? (topeng ada tidak di keraton bu?), mereka menjawab: tidak ada. Topeng itu merupakan sesuatu yang sudah tersingkirkan dari hasanah keraton, baru awal 90-an, ada seorang pangeran bernama $\mathrm{H}$. Yusuf Denda Brata, patih dalem keraton kacirebonan memanggil Mang jana dari Selangit, maestro topeng dari klangenan kabupaten Cirebon, bapaknya Inu Kertapati. Pangeran Yusuf berkata: mang mene, ajari ki.. sing diajarane: elang Hery, elang Toni, elang Iyan dan lainnya, putra-putri keraton kacirebonan. Saya saat itu tidak mau. Saya lebih tertarik kepada makna simbolik, sedangkan Elang Hery dan kawan-kawan lebih kearah teknik musik dan penampilan tarinya. Jadi, berdasarkan minat sendir-sendiri. Bang Hery, diajari tariannya dan saya diajari langsung oleh pangeran $H$. Yusuf Denda Brata makna simboliknya, yakni ditinjau dari dakwahnya itu.

Mang Jana selangit dipanggil seminggu sekali. Wa Yusuf yang membayari. Setelah belajar sukses, setiap ada event, ada kegiatan di keraton ditampilkan, setelah ditampilkan ternyata bagus, akhirnya makin banyak orang yang mau belajar. Tari topeng kemudian di bawa ke keraton kanoman dikembangkan oleh elang Mamat. Dari sana dibawa ke keraton kasepuhan dan akhirnya semua keraton itu, ramai-ramai kalau ada tamu menampilkan topeng. Sebelumnya tidak ada topeng di keraton. Perkembangan selanjutnya, pak Handoyo dari plumbon member polesan-polesan seni pertunjukannya, sehingga ada konfigurasi di tari topeng. Hal itu, jelas sudah bukan dakwah lagi, sudah pariwisata. Topeng yang semacam itu pernah dipertunjukkan di panggung budaya 
Sunyaragi, Elang Hery menampilkan 100 orang penari. Ya boleh-boleh saja. Kata Wa Ucup, sebab di dunia seni itu, seorang seniman mau apapun juga, seni itu tidak ada yang salah boleh saja, memang ada yang pakem, kalau yang pakem seperti pancawanda, Wa ucup marah sekali kalau diubah-ubah. Kalau mau menciptakan hal baru dalam tari topeng, silahkan. Itu bagus.

Sementara itu, upaya yang dilakukan para seniman dalam mengemas pertunjukan tari topeng agar tidak hanya sebagai media hiburan, tetapi bisa memiliki multi fungsi. Beberapa seniman telah membuat improvisasi, namun tidak menghilangkan akar dari kesenian. Karena kesenian memiliki tiga fungsi (Trismara Bhakti), seni sebagai hiburan, penyampaian pesan dan pendidikan. Misalnya, Bambang menjelaskan bahwa sebagai seniman, ia dan teman-temannya di Cirebon sudah dari dulu bergelut dengan ranah dakwah dalam bentuk kesenian dan budaya. Ia sudah menciptakan tari topeng beling, untuk dakwah. Tari topeng jenis ini belum ada di dunia manapun. Pada pertunjukan tari topeng beling terdapat adegan menginjak-injak pecahan kaca, disiram dengan minyak tanah ( lengah lantung), dinyalakan dengan api, kemudian diinjak-injak menggunakan topeng, Tarian ini menggunakan dua topeng dengan dua karakter. Topeng putih menggambarkan karakter baik dan topeng hitam menggambarkan karakter buruk. Pertunjukan tari topeng beling pertama kali di tampilkan pada festival Keraton. Dari peristiwa itu banyak orang terkagum-kagum dan bertanya-tanya Tarian apa itu..?, saat itulah kita menjelaskannya.

Contoh lain, Menurut Bambang, pada waktu kecil, saya bertanya pada Mamang Elang Ibrahim (Wa Oo), bagaimana sih debus itu?, beliau mengatakan: oh iya, waktu saya kecil dulu, saya bisa melihat orang main debus caranya begini, begini, mereka menceritakan itu kepada saya, lalu saya menghayal dan mencoba menghidupkan kembali, setelah latihan 1 bulan saya praktekkan bersama Elang Hery, ternyata golok yang saya tusukan ke perutnya, gagal, keluarlah nasi dari perut, dan sampai sekarang masih ada bekas lukanya. Contoh lain, Elang Mamat, ketika mau menampilkan pertunjukan debus di hotel Bentani, ternayata goloknya tertinggal, dan akhirnya mengambil golok dari dapur hotel yang biasa dipakai untuk memotong daging. Pertunjukan saat itu juga gagal, terjadilah insiden berdarah-darah. Artinya, dari kejadian-kejadian itu, membuktikan bahwa para seniman sudah melakukan kerja keras untuk menghidupkan kembali kesenian Cirebon sampai berani seperti itu. Melalui trial and error itu dilakukan beberapa kali, meskipun lebih banyak erornya daripada berhasilnya. Artinya, dalam mencoba 
merevitalisasi kesenian tradisi itu yang terpenting adalah kita terus berpikir. Proses berfikir inilah yang kita perlukan juga dalam mengembangkan dakwah melalui seni.

\section{Hambatan Merevitalisasi Tari Topeng sebagai Media Penyebaran Ajaran Islam di Cirebon}

Menurut Elang Heri, dalam pengembangan seni tari topeng ke depan, jelas kita dihadapkan kepada kendala-kendala. Secara real memang hal itu harus dipikirkan lagi, bagaimana kita mengenalkan dan menggunakan media seni itu untuk dakwah. Intinya, berlaku untuk semua seni apa saja. Kalau dulu topeng, sekarang kita bisa berkembang ke media seni lainnya, yang jelas media seni untuk dakwah itu harus tetap ada. Tidak bisa dipungkiri bahwa ada sejarah-sejarah lama yang harus kita kenang, karena itu bisa menjadi salah satu dasar bagaimana mengembangkan dakwah melalui media-media seni. Ketika berbicara Revitalisasi, artinya, bagaimana kita mengemas ulang, bagaimana di era sekarang tari topeng itu bisa menarik. Kendalanya ada dua: pertama, topeng adalah seni tradisi, seni lama yang harus dikenalkan kepada orang modern, orang yang belum pernah melihat, dan tari topeng itu merupakan tarian lokal. Artinya, pengembangan topengnya saja sudah susah, karena itu perlu usaha yang lebih keras untuk pengenalannya. Kedua, ada sisipan dakwahnya. Tetapi, kalau kita melihat dakwah melalui seni sebenarnya bisa fleksibel, karena awalnya adalah hiburan atau tontonan, yaitu tontonan yang bisa menjadi tuntunan. Tontonan itu bisa apa saja yang bisa ditampilkan. Ketiga, meskipun ada pakem, kita masih bisa mengembangkan, contohnya adalah topeng beling, ketika dikemas dipadukan dengan debus, ternyata lebih menarik dan lebih disukai oleh masyarakat secara umum masa itu. Buktinya, ketika topeng beling itu dibikin dan disajikan ternyata diterima masyarakat. Jadi, seperti itulah tehnik mengemas, bagaimana kita bisa mengemas di era sekarang dan tidak melupakan tradisi, namun kita juga harus mengimbangi dengan keadaan sekarang. Begitulah upaya memadukan unsur dakwah dengan seni. Kalau untuk kajiannya sudah banyak kajian-kajian lama tentang itu, dan kita bisa mencontoh kajian itu untuk diterapkan ketika kita akan menyampaikan dakwah. Intinya, untuk melakukan upaya revitalisasi tari topeng diperlukan kerja keras, termasuk dalam melakukan usaha untuk melebur kesenian dengan dakwah.

Kendala lain dalam upaya revitalisasi topeng adalah perkembangan jaman. Perkembangan zaman, memaksa kita untuk menjadikan kesenian tradisonal bersaing dengan kesenian modern (popular) yang dapat 
dijadikan sebagai komoditas dan mendatangkan keuntungan materil, terutama melalui pariwisata. Maka topengpun dikemas sebagai paket wisata, atau sering disebut paket hemat . hal itu menghilangkan banyak substansi-substansi dari esensi-esensi kesenian. Bagaimana upaya menyiasatinya?. Menurut Opan Safari, sebagai pengalaman, tahun 2014 pak Endo Suwanda, pernah mengundang beberapa orang dari ITB, UNPAD, STSI dan lainnya, dari semua keahlian termasuk saya, untuk merevitaslisasi sebuah adegan. Adegan yang direvitalisasi itu adegan perang hebat, kebetulan yang memerankan itu Nyai Nirong (sudah wafat) dan Pak Sujana. Di sana dari berbagai disiplin ilmu memberikan pandangan dan pemikirannya untuk merevitalisasi tari topeng. Dari gerakannya, visualnya, dan lainnya, ternyata itu rekaman yang diambil oleh pak Endo adalah tarian yang dilakukan di keraton kesepuhan. Artinya, tempatnya di Cirebon, penarinya orang Cirebon, tetapi mencari rekamannya ternyata di Kalifornia, itu mahal sekali. Begitu juga, kalau kita mau merevitalisasai gerakan-gerakan yang ada unsur dakwahnya, semua unsur harus terlibat bukan hanya seniman, tetapi dari pemerintah (Budpar), dari kampus, masyarakat, agamawan dan lainnya untuk penyelamatan itu penting dilakukan.

Bahkan menurut Bambang, di Cirebon itu terlalu kaya, Kesenian yang berhubungan dengan dakwah itu sangat banyak. Karenanya pekerjaan rumah kita juga banyak, topeng saja sudah sekian jelimetnya. Baru-baru ini Elang Heri kedatangan Richard Not dan Mama Erick. Mereka mendalami gamelan renteng, yaitu gamelan untuk menyambut tamu agung, dalam gamelan itu dibutuhkan sekitar 50 lagu, yang dikuasai oleh mama Erick berapa lagu, Elang Heri juga menguasai sebagian kecil saja, disitulah Elang Heri banyak belajar kepada Mama Erick. Artinya, saat ini orang cirebon ketika ingin belajar kesenian asli Cirebon, itu harus belajar kepada orang asing. Di Selandia baru itu ada Alan Tomas, Proffesor of music, ternyata musik yang dikuasainya adalah gamelan Cirebon. Saya ketika SMP, belajar gamelan Cirebon dari Alan Tomas. Batik kuno yang halus khas cirebon itu, ternyata adanya di Jepang. Bendera Cirebon itu ternyata adanya di Roterdam. Kesenian yang sangat jelas nuansa dakwahnya adalah Wayang golek, termasuk wayang kulit Cirebon, itu memiliki kepribadian sendiri, kepribadian Islam, kepribadian dakwah. Contohnya, Arjuna itu disimpannya di depan dekat dengan dalang. Duta sewu yang raksasa (jahat) disimpanya di paling ujung jauh dari dalang. Sehingga, Arjuna ketika dicabut oleh dalang nyabutnya itu secara halus, pelan-pelan, dan arjuna itu lambang megeng, itu menggambarkan orang puasa. Sedang menahan nafsu, dekat dengan 
Allah, tentunya tidak meninggalkan sholat, puasa. Disitulah, makna simbolisnya bahwa Arjuna itu symbol orang yang didekatkan dengan penguasa jagat raya. Seperti gambaran orang yang sakratul maut, Arjuna itu dicabutnya secara pelan dan halus, sedangkan Duta sewu itu gambaran orang jahat, ketika dicabut oleh dalang dari gedebong pisang yang paling ujung, harus kuat, bahkan perlu bantuan tiga orang. Gambaran itu pula yang terjadi pada saat sakratul maut yang terjadi pada sosok duta sewu (orang jahat).

Menurut Nur Annani, selama ini seniman menghadapi banyak hambatan dalam upaya merevitalisasi tari topeng. Topeng Losari tidak akan selalu ada pada perjalanan mulus semuanya pasti memiliki tantangan, tetapi kalau seniman selalu berada di zona aman tidak akan menjadi manusia yang berpikir untuk maju. Jadi, apapun rintangan, cobaan, ujian, sudah seharusnya diterima dan dihadapi. Seorang seniman harus memiliki sifat legowo. Kalau tidak ada orang yang mengundang kita, ya tidak apa-apa, ada orang yang mengundang kita bersyukur, yang pentingkan kita terus bergerak. jangan hanya diam di tempat. Banyak sekali aktivitas yang bisa dilakukan dari pada hanya diam diri. Sebagai seorang seniman tentunya semua berharap bahwa setiap saat proses perjalanan karir mereka tetap, tidak akan berhenti. Tetapi, orang pasti ada masanya. Yang paling harus kita pahami bahwa sebagai seniman itu musuh utamanya ialah masa. Masanya nenek moyang kita itu berbeda dengan masanya kita (Wawancara dengan Nur Annani, oktober 2016).

Jadi, bagaimana kita sebagai generasi muda atau sebagai orang yang ada pada masa kekinian itu harus bisa lebih memahami bahwa kesenian yang kita geluti sekarang, menjadi tanggungjawab kita sekarang. Pertama, bagaimana kesenian tari topeng tetap dikenal masyarakat secara luas. Kedua, jangan puas hanya bermain pada tingkat lokal, tetapi mau berusaha untuk go public dan go internasional. Karena kalau kita hanya besar di Cirebon saja, orang tidak akan mengenal apa yang kita pelajari, tetapi kalau kita belajar go internasional, misalnya dengan membuka jaringan atau link, dengan memanfaatkan kecanggihan teknologi saat ini, seperti melalui media sosial: Facebook, tweeter dan sejenisnya, kita dapat mempromosikan diri melalui tari topeng, Ketiga, adalah bagaimana kita bisa bersosialisasi dengan masyarakat luas, bahwa apa yang kita pelajari, apa yang kita geluti itu adalah satu hal yang memang harus dikembangkan, bukan cuma dilestarikan. Melalui sosialisasi yang terus menerus orang akan banyak mengetahui kesenian tradisi, jangan sampai orang hanya mengetahui kesenian modern saja. Cara utama kita bisa 
mengenalkan kesenian kita ke luar adalah dengan bekerjasama dengan kementrian budaya dan pariwisata.

Menurut Elang Heri, ketika saya ingin mengenalkan kepada generasi muda atau anak-anak, awalnya memang susah mengenalkan kesenian Cirebon ini, karena ketidaktahuan mereka, apalagi dikenalkan dengan misi dakwah dari kesenian tersebut. Jika dilihat dari sisi pengembangan, seni itu adalah hiburan. Hiburan yang tadinya agak susah diterima, karena bersifat tradisional dan tidak dikenal oleh masyarakat luas, maka bagi seniman atau praktisi seni ada dua tantangan dalam membewarakan kesenian itu. Tantangan pertama, bagaimana kita mampu mengenalkan kepada masyarakat melalui organisasi atau kerjasama dengan berbagai pihak. Tantangan kedua adalah menyebarkan misi dakwah yang ada dalam kesenian itu. Artinya, dari sisi praktisi (pelaku seni) bahwa nilai-nilai dakwah itu harus dilakukan secara perlahan-lahan ditanamkan pada masyarakat, termasuk kepada generasi muda. Cara yang pernah dilakukan adalah melalui ujian kelulusan. Setiap 6 bulan sekali di sanggar Seni Tari topeng itu mengadakan ujian kelulusan, selain ujian praktek seni tariannya sendiri juga anak-anak diuji secara tertulis dengan tugas membuat makalah tentng tari topeng, supaya anak-anak bisa mengerti lebih jauh tentang topeng.

\section{PENUTUP}

Berdasarkan paparan- paparan pada bab sebelumnya, maka penulis membuat kesimpulan sebagai berikut: Pertama, Pemanfaatan kesenian tari topeng sebagai media alternatif dalam penyebaran dakwah Islam. Pertama kali dikembangkan oleh Sunan Kalijaga, Sultan Penggung dan Sunan Gunung Jati. Selanjutnya, tari topeng dikembangkan oleh keturunannya baik di keraton kesepuhan, keraton kanoman dan keraton kacirebonan. Pada masa awal (pra-Islam) topeng sudah terkenal sebagai sebuah suguhan atau tontonan yang sangat disukai oleh masyarakat, sama seperti wayang. karena itulah, tari topeng dijadikan sebagai media dakwah yang paling efektif.

Kedua, Makna-makna yang terkandung dalam tari topeng dapat menjelaskan tentang pengingat kepada Sang Maha Esa, Sang Pencipta, Simbol-simbol tari topeng menjelaskan nilai-nilai moral yang menjadi muatan untuk berdakwah. Misalnya, tentang perjalanan hidup manusia dari mulai masa kanak-kanak hingga dewasa, nilai-nilai kepemimpinan, 
kebijaksanaan, cinta bahkan murka serta nilai-nilai luhur lainya. Bagi masyarakat sendiri makna-makna dapat dijadikan sebagai panutan dan tuntunan. Oleh karena itu, makna-makna simbolisnya selaras dengan ajaran Islam. Hasil kreasi asli para penyebar ajaran Islam di tanah Jawa (Wali), ini bisa dikemas dan ditampilkan melalui alat-alat atau media yang menyenangkan dan mudah untuk diterima semua kalangan, tanpa meninggalkan substansi aslinya sebagai media dakwah, pendidikan dan seni (hiburan).

Ketiga, Peranan penting tari topeng pada masa-masa awal penyebaran Islam di Jawa Barat, meniscayakan kesenian ini terus menerus direvitalisasi. Upaya revitalisasi dilakukan dengan melibatkan berbagai keahlian dari berbagai disiplin ilmu baik dari kalangan perguruan tinggi, seniman, budayawan, sejarahwan dan Dinas kebudayaan dan Pariwisata. Begitu juga, kalau kita mau merevitalisasai gerakan-gerakan yang ada unsur dakwahnya, semua unsur harus terlibat bukan hanya kita untuk penyelamatan itu penting. $\mathrm{Hal}$ ini telah dilakakuan baik pemerintah, seniman, budayawan maupun akademisi dan terutama kalangan keraton dengan strategi masing-masing.

\section{DAFTAR PUSTAKA}

Ali, A. (2007). Tradisi Kliwon Gunung Jati: Model Wisata Religi Kabupaten Cirebon. Yogjakarta: Cakrawala.

Arsyad, A. (2002). Media Pembelajaran. Jakarta: PT RajaGrafindo Persada.

Buchori, S., \& Kuswilah, W. (2001). Sejarah Kerajaan Tradisional Cirebon. Jakarta: CV. Sukoredjo Bersinar.

Caray. (2008). Definisi Revitalisasi. Diambil 12 Februari 2017, dari https://www.scribd.com/ document/39085881/Revitalisasi

Dahuri, R., Irianto, B., \& dkk. (2004). Budaya Bahari: Sebuah Apresiasi di Cirebon. Jakarta: Percetakan Negara RI.

Effendy, O. U. (1981). Dimensi-dimensi Komunikasi. Bandung: Alumni.

Fachriya, I. A. (2011). Tari Topeng Endel dalam Perkembangan dan Pelestarian Kesenian Khas Tegal, Diserta. Universitas Negeri Semarang.

Fitriyah, D., \& Pamungkas, Y. H. (2015). Perkembangan Tari Topeng Gethak di Kabupaten Pamekasan pada Tahun 1980-2005. Avatara, 3(3), 6046015.

Hardi, T. R. (2014). Dakwah Sunan Gunung Jati dalam Proses Islamisasi di Kesultanan Cirebon Tahun 1479-1568, Skripsi. Universitas 
Negeri Yogyakarta.

Harmoko. (1986). Komunikasi Sambung Rasa. Jakarta: Sinar Harapan.

Hayuning, K. (2015). Tari Topeng. Diambil 2 Februari 2017, dari http:// ragamtariindonesia.weebly.com/tari-topeng.html

Hidayat, D. N. (2007). Pengantar Komunikasi Massa. Jakarta: PT.. Raja Grafindo Persada.

Irianto, B., \& Fatimah, S. (2009). Syekh Nurjati: Perintis Dakwah dan Pendidikan. Cirebon: STAIN Press.

Reynaldi, G. (2014). Islamisasi Tatar Sunda Melalui Kultur dan Struktur. Diambil $11 \quad$ Februari 2017, dari http:// suakaonline.com/890/2014/02/24/islamisasi-tatar-sundamelalui-kultur-dan-struktur/

Suanda, T. A. (2009). Topeng Cirebon. Bandung: STSI.

Sugiarto, A., Nugraheni, T., \& Suryawan, A. I. (2013). Tari Topeng Kelana Udeng Di Sanggar Mulya Bhakti di Desa Tambi Kecamatan Sleyeg Kabupaten Indramayu. Ringkang, 1(3), 18.

Sulendraningrat. (1975). Sejarah Cirebon: Silsilah Sunan Gunung Jati Maulana Syarif Hidayatullah. Cirebon: Lembaga Kebudayaan Wilayah III Cirebon.

Wahidin, D. (2006). Potensi Kesenian Daerah Cirebon. Cirebon: Dinas Kebudayaan dan Pariwisata.

Wildan, D. (2012). Sunan Gunung Jati. Ciputat: Salima. 